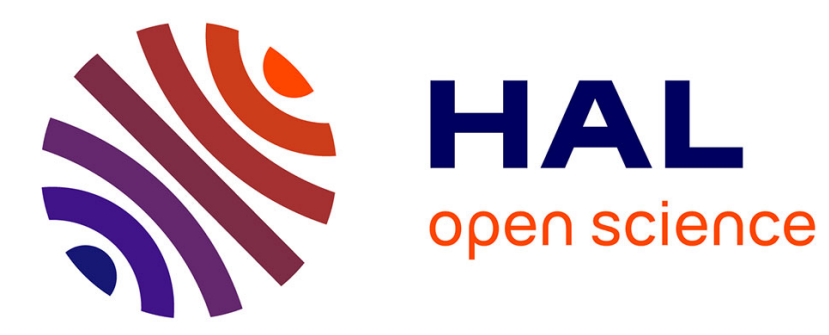

\title{
Blowing the rivers: Regional-scale control of the drainage network by wind in northern Kalahari (Africa)
}

Marc Jolivet, Olivier Dauteuil, Louis Gaudaré

\section{To cite this version:}

Marc Jolivet, Olivier Dauteuil, Louis Gaudaré. Blowing the rivers: Regional-scale control of the drainage network by wind in northern Kalahari (Africa). Geomorphology, 2022, 398, pp.108039. 10.1016/j.geomorph.2021.108039 . insu-03431960

\section{HAL Id: insu-03431960 https://hal-insu.archives-ouvertes.fr/insu-03431960}

Submitted on 17 Nov 2021

HAL is a multi-disciplinary open access archive for the deposit and dissemination of scientific research documents, whether they are published or not. The documents may come from teaching and research institutions in France or abroad, or from public or private research centers.
L'archive ouverte pluridisciplinaire HAL, est destinée au dépôt et à la diffusion de documents scientifiques de niveau recherche, publiés ou non, émanant des établissements d'enseignement et de recherche français ou étrangers, des laboratoires publics ou privés. 


\section{Journal Pre-proof}

Blowing the rivers: Regional-scale control of the drainage network by wind in northern Kalahari (Africa)

Marc Jolivet, Olivier Dauteuil, Louis Gaudaré

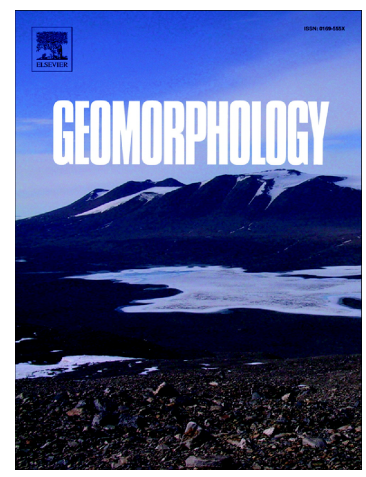

PII:

S0169-555X(21)00447-5

DOI: https://doi.org/10.1016/j.geomorph.2021.108039

Reference:

GEOMOR 108039

To appear in:

Geomorphology

Received date:

6 September 2021

Revised date:

10 November 2021

Accepted date:

10 November 2021

Please cite this article as: M. Jolivet, O. Dauteuil and L. Gaudaré, Blowing the rivers: Regional-scale control of the drainage network by wind in northern Kalahari (Africa), Geomorphology (2021), https://doi.org/10.1016/j.geomorph.2021.108039

This is a PDF file of an article that has undergone enhancements after acceptance, such as the addition of a cover page and metadata, and formatting for readability, but it is not yet the definitive version of record. This version will undergo additional copyediting, typesetting and review before it is published in its final form, but we are providing this version to give early visibility of the article. Please note that, during the production process, errors may be discovered which could affect the content, and all legal disclaimers that apply to the journal pertain.

(C) 2021 Published by Elsevier B.V. 
Blowing the rivers: regional-scale control of the drainage network by wind in northern Kalahari (Africa).

Marc Jolivet $^{1}$, Olivier Dauteuil ${ }^{1}$, Louis Gaudaré ${ }^{1}$

${ }^{1}$ Géosciences Rennes, CNRS, Univ Rennes, UMR6118, F-35000, Rennes, France

marc.jolivet@univ-rennes1 - +33(0)2 23236746

olivier.dauteuil@univ-rennes1.fr

$\underline{\text { louis.gaudare@gmail.com }}$

Short title: Influence of wind erosion on regional d aa age network. 


\section{Abstract}

Understanding the impact of aeolian processes on the regional-scale dynamics of fluvial systems in semi-arid regions is a major issue in the framework of climate change. Although the interactions between aeolian and fluvial processes have been studied on a meter to kilometer scale, few studies have upscaled to the regional scale. Using satellite images and SRTM-1 digital elevation models we document the formation of parabolic dunes and foredunes along the main rivers of the southern Angolan Plateau and northern Kalahari Basin (Africa). We demc `trate that these aeolian features derive from interactions between the morphology of the drail age system, the wind pattern, the vegetation cover and the transport capacity of the rivers. As a retro-action phenomenon, the progradation of parabolic dune fields induces tens-of- 1 ilor leters shifting in rivers courses in the northern Kalahari basin. The mechanism proposed is is implications in terms of fluvial dynamics, river capture, geometry of clastic deposits in '

\section{Introduction}

In arid and semi-arid envir Jnı. ents redistribution of clastic sedimentary material results from the interactions between fluvial and aeolian erosion and transport processes (Maroulis et al., 2007; Williams, 2015). A number of studies have addressed the influence of fluvial valleys and rivers on the propagation of a dune field (Bullard et al., 2000; Wang et al., 2019) or on modifying the shape of dunes (Bullard and Nash, 2000). Others addressed the effects of dune propagation on river systems, such as damming or enhanced avulsion frequency (Krapf et al., 2003; Liu and Coulthard, 2017). Finally, some studies assessed the morphologies of riverbeds in association with the type and distribution of riparian dunes, themselves controlled by vegetation, basement morphology or aeolian - fluvial interaction parameters ( $\mathrm{Li}$ et al., 2020, 2021). These studies described in detail the processes of interaction between rivers and dunes at a meter to kilometer scale but did not upscale 
their effects on river morphologies to the regional scale (tens or hundreds of kilometers). The question thus remains of how interactions between fluvial and aeolian systems may shape regional topographies and drive landscape dynamics? Among many possible approaches to answering that question, we address the effects of such interactions on the long-term dynamics of drainage networks. The southeastern region of Angola, between the Cubango and Cuito rivers represents a transition area between the upper part of the fluvial system on the elevated, humid plateau of central Angola and the distal semi-arid to arid alluvial plains of the Okavango Basin in Namibia and Botswana (Figs. 1 and 2). The region includes parts of the E-W r riented, northern Kalahari dune field now considered as inactive or nearly inactive (Thomas, 19 24). This dune field is crossed by a series of rivers flowing south towards the Okavango Delta i i $\perp^{\text {ntr }}$ wana (Fig. 1). The unconsolidated late Cenozoic aeolian deposits of northern Kalahari are trac tionally divided into several sub-dune fields separated by the largest rivers (e.g., Thomas, ; 988). The dunes are more developed west of each channel, suggesting that a large part of a a slian sediment is sourced from alluvial material (Thomas, 1988). It has been established that at local scale, the small tributaries to the large rivers developed in a E-W direction along at interdunes of the major linear dunes. The architecture (location, direction, size) of the secc ndar $y$ drainage system is thus strongly controlled by the aeolian features (Thomas et al., 2000).

This setting represents a te $x$ tbo $) \mathrm{k}$ opportunity to describe the large-scale influence of the aeolian system on the river network Using satellite images and digital elevation models, we demonstrate the major impact of the aeolian processes on the drainage pattern and dynamics, including location and shape of rivers, alluvial sand recycling, riverbank erosion, changes in river courses and enhanced captures. All these processes are favored by the very flat regional topography and the poorly consolidated Kalahari deposits supporting the fluvial and aeolian systems.

\section{Climate, major dune fields and geology of southern Angola, Zambia and northern}

\section{Kalahari.}




\subsection{Climate and dune fields.}

The region considered in this study is characterized by an annual rainfall of about $1200 \mathrm{~mm}$ to the north to about $600 \mathrm{~mm}$ to the south near the border with Namibia (Fig. 2A) (Carvahlo et al., 2017; Huntley, 2019). Based on the Köppen-Geiger classification, climate ranges from warm temperate (with dry and hot summers) north of about $16^{\circ} \mathrm{S}$, to hot arid steppes to the south (Fig. 2B, C) (Kottek et al., 2006). Finally, data obtained from the Copernicus ERA5-Land monthly average model (Muñoz Sabater, 2019) indicate present-day wind mainly blowing from the east with a small dispersal towards ENE and SE (Fig. 2C).

Northern Namibia, southern Angola and western Zambia (Fig. 1) a e covered by large, stabilized dune fields (i.e., vegetated dunes without active aeolian $\mathrm{d}^{\prime} \mathrm{sr}^{\prime} \mathrm{a} \mathrm{c}^{\prime}$-ment of sand, e.g., Yizhaq et al., 2007) belonging to the Mega Kalahari sand sea. Al+ $10 u \underline{h}$ still easily identified from satellite images and high-resolution Digital Elevation M.u'als (DEMs), the paleo-dunes are strongly degraded and may represent only the low $f \eta^{\prime} a_{1}{ }^{+}$of the former active features (O'Connor and Thomas, 1999) (Fig. 3). The aeolian paleo-sy ${ }^{+}-\mathrm{m}$ is mainly composed of linear dunes (Thomas, 1984), although large parabolic dunes a ${ }^{\mathcal{H}}$ lunette dunes are present (Fig. 3). Lunette dunes are associated to shallow depressions ( alled "dambos" in Zambia) subjected, under the present-day climate conditions, to seasonal $r$ interannual flooding from rainfall-water accumulation. The presence of water allows ve seta ion to grow and the accumulation of peat in the depressions (Boast, 1990; Burrough et al. 2015) While the present-day wind direction is coherent with the direction of those dunes, the annual precipitation values of about $700 \mathrm{~mm}$ (Fig. 2A) are not compatible with the growth of such aeolian features that require annual precipitation of less than $200 \mathrm{~mm}$ (O'Connor and Thomas, 1999). Optical luminescence, radiocarbon and pollen dating of the dambos soils and associated lunette dunes in western Zambia indicate dry-climate periods of deflation of the dambos and sand accumulation on the upper part of the lunette dunes at 13.7 $\pm 1.6,10.0 \pm 1.3$ and $5.9 \pm 0.7$ ka. Peat accumulation in the depression initiated around $2.8 \mathrm{ka}$ indicating the onset of a wetter period (Burrough et al., 2015). O'Connor (1997) reported activity of the lunette dunes as old as $57 \pm$ 
$6 \mathrm{ka}$, suggesting that alternation between wet and dry periods as been a long-lasting landscape dynamics process, the organic-rich deposits being largely lost by deflation. Linear dune fields have also been investigated using luminescence dating in western Zambia (O'Connor and Thomas, 1999; Burrough et al, 2015), northern Namibia (Thomas et al., 2000, 2003), western Zimbabwe (Stokes et al., 1997, 1998; Munyikwa et al., 2000), southeastern Namibia (Stone and Thomas, 2008) and southern Kalahari (Thomas et al., 1997; Stokes et al., 1997; Bateman et al., 2003; Telfer and Thomas, 2007; Telfer, 2011) (Fig. 1). Using a statistical approach to determine the variations in sand accumulation rates in dunes (Accumulation Index), Thomas and Bailey (2017) showed that the dune field in western Zambia was active around $35 \mathrm{ka}$ while otl ers how peak activity in the 16 to $10 \mathrm{ka}$ age interval. The absence of old ages in most of the $\mathrm{d} \cdot \mathrm{n}$. fir $/ \mathrm{ds}$ is not related to a difference in onset of activity but rather to the recycling of the ol $\mathrm{r}$ r a sposits during subsequent reactivation periods (Bailey and Thomas, 2014; Thomas and B at. v; 2017). In turn, Thomas and Bailey (2017) explain the absence of the youngest ages in $t^{1} \ldots$ L $Z_{a}$ mbian field either through its location in tropical areas less affected by drier climate periods (Th mas and Burrough, 2012), through removing of the youngest sand deposits during more $\mathrm{r}$ et ${ }^{+}$aegradation of the dunes (McFarlane et al., 2005), or simply by the smaller amount of a'ailaule data. The aeolian activity was probably discontinuous with periods of increased humicitv that impeded sand mobilization (Thomas et al., 2000, 2003). However, in the Kalahari $c$ ine fields situated in tropical regions such as Zambia, periods of peak sand accumulation occur im nediately after periods of wet conditions. This suggests that, at least during the beginning of the dry period, most of those dunes are fed by aeolian recycling of fluvial sand transported during the wet periods in the major rivers situated downwind (Thomas and Bailey, 2017).

\subsection{Geology.}

The geological series exposed in the study area are composed of an Archean to Proterozoic crystalline basement belonging to the Angolan Shield, uncomformably covered by the Late Cretaceous - Cenozoic clastic sediments of the Kalahari Group that extend over a large part of 
southwestern Africa, from northern Angola to northern South Africa (e.g., De Araújo et al., 1988;

De Carvalho et al., 2000; Hanson, 2003; Haddon and McCarthy, 2005) (Fig. 2D). Some Late Jurassic to Early Cretaceous continental series are exposed farther to the north but have not been mapped south of $15^{\circ} \mathrm{S}$ (De Araújo et al., 1988). Regionally, the thickness of the Kalahari Group sediments is variable, locally reaching up to $450 \mathrm{~m}$ in southern and central Angola (thickness ranges from 0 to $350 \mathrm{~m}$ in our study area (Fig. 2D)) (Haddon and McCarthy, 2005). A detailed description of the Kalahari Group sediments together with a compiled isopach map can be found in Haddon and McCarthy (2005) with many references specific to each sediment $r /$ unit. Although local variations exist, the series are generally composed of a basal unit forn ed $1 \mathrm{y}$ alluvial conglomerates and gravels. These coarse sediments are covered by calcarf o s r lays mixed or interbedded with sandstones. The following unit is composed of sands ${ }^{+}$nes generally considered as braided river deposits. This unit is poorly consolidated except fr. i ie development of extensive duricrusts in the pans (pans are flat, closed depressions of v?.: 'us rigin including karstic erosion, wind deflation, salt weathering or lacustrine processes, e.g., L'hritton et al., 1990; Goudie, 1991; Wormald et al., 2003). The final unit is composed if inconsolidated sand of both fluvial and aeolian origin characterized by the dune fields des ribeu above.

\section{Rivers and aeolian dun $s$ m rphologies in southern Angola.}

\subsection{Methodology ans data.}

Topographic data were obtained from the NASA Shuttle Radar Topography Mission (SRTM-1) digital elevation model (1 arc second - $30 \mathrm{~m}$ - horizontal resolution) (DOI:/10.5066/F7PRTFT). Topographic maps and elevation profiles were drawn using the Generic Mapping Tool (GMT) software (Wessel and Smith, 1991). River longitudinal profiles were first digitalized on Google Earth ${ }^{\circledR}$ before corresponding altitudes were extracted from the SRTM-1 model using GMT. Finally, wind data were obtained from the Copernicus ERA5-Land monthly average model $\left(0.1^{\circ} \times 0.1^{\circ}\right.$ 
horizontal resolution) using the $10 \mathrm{~m}$ above ground wind speed and direction data (Muñoz-Sabater, 2019).

\subsection{River morphologies.}

The rivers sourced in the Angolan plateau are flowing southward on a near N-S trend, parallel one to the other before several of them are diverted on a large westward curve on reaching the flat, semi-arid northern edge of the Okavango Basin. Bending occurs immediately south of the topographic break in slope between the plateau and the plain and immediately north of the limit defined between the warm temperate (Cwa) and arid steppe (Bsi ) climate domains (Fig. 2C). No apparent link exists between the change in direction of the riv $>$ rs ; nd the surface lithology (Fig. 2D). Only the large Cubango and Cuito rivers remain on a r za: $\mathrm{N} S$ track.

The riverbed topographic profiles record variations in lyna nics between the different rivers (Fig. 4A). The Cubango and Cuito rivers show a const „11, very low mean longitudinal slope over the complete measured profile $(0.012 \%$ for th- C.hango excluding the section above a marked knickpoint (k1), and $0.018 \%$ for the Cuito), wi ile the other rivers have a generally convex profile when reaching the lowlands and a sir,n): cantly higher mean slope over the complete measured profile (between $0.034 \%$ for the L ass1ı.ga to $0.065 \%$ for the Cuatir) (Fig. 4A). Satellite images

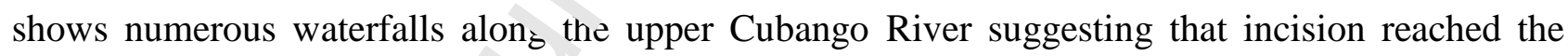
consolidated-rock series be ow he weakly consolidated, weathered upper members of the Kalahari Group sediments (Thomas und Shaw, 1991; Haddon and McCarthy, 2005). This explains the occurrence of the major knickpoint (Fig. 4A). A similar incision level could be expected in the Cuito River based on altitude correlation of the riverbed, although no knickpoint is observed along the profile drawn in this study (Figs. 2C and 4A). Finally, two knickpoints are observed in the upper part of the Cuafir River profile (k2 and k3), although based on the available data no link could be made with changes in riverbed lithology (but this possibility cannot be excluded).

North of $16^{\circ} \mathrm{S}, \mathrm{E}-\mathrm{W}$ topographic profiles perpendicular to the drainage system show that the western banks of the rivers are generally steep (about 8 to 10\%) and display stepped terraces (Figs. 
2, 4B-C, 5 and SupFig. 1). Furthermore, the western banks are systematically underlined by a 4 to 5 $\mathrm{km}$ wide, up to $60 \mathrm{~m}$ high ridge formed by a continuous dune cordon (see below). In contrast, the eastern bank is marked by a more gradual slope (Figs. 4B-C, 5 and SupFig. 1).

South of $16^{\circ} \mathrm{S}$, regional E-W topographic profiles perpendicular to the drainage system along the main axis of the releasing bends show a series of characteristic semi-conical structures, the most typical being related to the Cueio, Cuafir and Luassinga rivers (Fig. 4D). The western bank of the rivers is again systematically marked by a 60 to $80 \mathrm{~m}$ high steep slope (Fig. 2C). Although no continuous dune cordons are observed except along the majo Cuito and Cubango rivers, the topography is rugged, mainly associated with large parabolic d ines and blowout depressions (see below) (Fig. 2). The eastern bank of the westerly bent Cue o, Fufir, Cuatir and, to a minor extent, the Luassinga River, shows a roughly $20 \mathrm{~km}$ long grad al $\mathrm{n}$ e toward a plateau at about $1220 \mathrm{~m}$ in altitude on the considered section (Fig. 4D). Exref: for the Cueio River (that connects to the Cubango River much farther north than the $r_{i .} \mathrm{r}$. : vers), the distance between each river is regular, ranging between 30 and $40 \mathrm{~km}$. The observec amount of entrenchment of the riverbed seems to depend on the apparent flowrate of th : vers (no flow measurements are available) and appears inversely correlated with the slope. 'ndeud, on the latitude of the regional E-W topographic profile (Fig. 4B), the major Cubango anc Cuito rivers (that display the lowest longitudinal slopes) have an altitude of $1140 \mathrm{~m}$ while th $2 \mathrm{sn}$ aller Cuafir and Cuatir (showing a higher longitudinal slope) have an altitude of $1160 \mathrm{~m}$ (Fig. D). In parallel, the Cubango and Cuito rivers are characterized by a well-defined active meandering riverbed all along their analyzed course (SupFig. 2A and 2F). In contrast, the westerly bent rivers show a well-defined meandering active bed north of the onset of bending and a poorly defined, braided- to anastomosed-like active bed within the bend region, characterized by vast swamps (SupFig. 2B to 2E). Assuming that the grain size of the transported material is similar in all rivers (mostly recycled aeolian and fluvial Kalahari sand), the variations between meandering and anastomosed/braided morphologies are probably reflecting an increase in sediment supply and/or the decrease in bed slope (Church, 1992; Rosgen, 1994). 
All the rivers forming the Cubango and Cuito drainage systems are flowing toward the Okavango graben in northern Botswana (Fig. 1). The entrenchment of those rivers is largely driven by incision following a Late Pliocene-Pleistocene drop in base level induced by the tectonic subsidence in the Okavango graben and the progressive evaporation of the vast lakes that filled a large area of the Okavango Basin during the Early Pleistocene - Holocene (Ringrose et al., 2005; Burrough et al., 2009; Moore et al., 2012; Riedel et al., 2014). This regressive erosion mechanism explains the formation of valleys several tens of meters deep.

\subsection{Dunes.}

On a kilometer to deca-kilometer scale, the riverbanks ar charıcterized by two types of aeolian features that - to our knowledge - have not yet beer disc ussed in the Kalahari region: riverine parabolic dunes and continuous, river-parallel dun $\iota$ srdons (Fig. 5). Because this work is entirely based on remote sensing datasets, the age of $\therefore$ os dunes was not constrained. Given their location and similar vegetation cover, their main peric ${ }^{1}$ of formation probably corresponds to that of the Middle Pleistocene - early Holocene l, nt *e and linear dunes dated in western Zambia (O’Connor, 1997; O’Connor and Thomas, 1999; Burı ough et al., 2015).

\subsubsection{Riverine parabolic a" "nes.}

As mentioned above, south of $6^{\circ} \mathrm{S}$, the topography of the western banks of the rivers, except for the major Cubango and Cili ${ }^{1}$ rivers, is mainly characterized by parabolic dunes. Fig. 6 illustrates the geometry of aeolian deposits around a portion of the Lwandilu River, a small tributary of the Zambezi River in western Zambia (Fig. 1), immediately east of our study area. The satellite image (Fig. 6A) and the interpreted geomorphological map (Fig. 6B) show the formation of large riverine (parabolic) dunes extending over up to about $5 \mathrm{~km}$ downwind of the river channel. Parabolic dunes generally occur in semi-arid to sub-humid areas with unidirectional winds and are frequently vegetated (Lancaster, 2009). However, they may also develop in more humid climates in regions of high sand availability such as coastal areas (Bailey and Bristow, 2004; Bertran et al., 2011; Swezey 
et al., 2016) or regions of strongly contrasted wet and dry seasons (Carr et al., 2016). In the example described here, the parabolic dunes (Fig. 6C) develop on the Liuwa Plains, a flat, grassy wetland itself supporting a dune field composed of grass-, shrub- and tree-covered transverse dunes (Fig. 6D). Although direct field investigation would be needed to assess this observation, satellite images suggest that some of the vegetated transverse dunes show active crests (Fig. 6E) with a frequency that would tend to increase toward the large parabolic dunes, suggesting that the activity of both dune sets is linked. These potentially active crests also suggests that the dunes are not totally stabilized. This activity may either reflect long-term interactions hatween vegetation, sand motion and variations in rainfall (e.g., Hesse and Simpson, 2006) or rec nt soil degradation linked to increasing human pressure (Belnap et al., 2009). Indeer', $\boldsymbol{n}$ he southwest Kalahari, below a vegetation cover of less than $14 \%$ the crest of veget ited dunes show evidence of reactivation (Wiggs et al., 1995; Thomas and Leason, 2005). T'ic increasing human pressure in the study area, especially through cattle grazing and fire - $7 y$ at al., 2014; Chidumayo, 2016 and references therein), may account for a renewed activity or the dunes (Wasson and Nanninga, 1986; Holmes et al., 2012; Abdourhamane Touré et al. 2,19). The eastern bank of the river is smoother than the western bank and marked by a $1 \mathrm{t}-2 \mathrm{kin}$ wide low-ridge-like structure formed by a thin sheet of aeolian sand colonized by trees. The ridge separates the river channel from a wet alluvial plain to the east, similar to the Liuw $₫$ Pl، ins.

The riverine parabolic dures described above are similar to those found along the western bank of the westerly-bent rivers in our study area, south of $16^{\circ} \mathrm{S}$. They form dune fields that extend westward until they reach the next river, some dunes clearly invading the floodplain (SupFig. 2).

\subsubsection{River-parallel dune cordons.}

North of $16^{\circ} \mathrm{S}$ and, to a lesser extend along the major rivers farther south, large continuous dune cordons form a 4 to $5 \mathrm{~km}$ wide, up to $60 \mathrm{~m}$ high ridge parallel to the river (Figs. 4B, 4C, 5 and SupFig.1). Theses ridges are supporting a dense vegetation cover of the Miombo-type forest characterized by large trees (Day et al., 2014; Goyder et al., 2018). The cordons are often separated 
from the active floodplain by terraces that are only located along the western bank of the rivers. The long axis of the cordon is systematically parallel to the riverbank, independently from the angle with the main wind direction (Fig. 5). Some places display dual cordons, composed of a narrow ridge along the river and a wider one farther west (Fig. 5). Downwind of those cordons, parabolic dunes are developing that seems to be sourced from the cordon. Both features are separated by a narrow depression.

\section{Discussion}

Based on the geomorphic data described above, this section dis usst $\mathrm{s}$ the evolution of the regional topography and the long-term evolution of the drainare ne work. We demonstrate that the occurrence of the rivers controls the formation of partic lar , eolian features. Coevally, retro-actions exist and we show that the river dynamics, at all $s r_{\text {all }} \mathrm{s}$, are largely controlled by aeolian processes (Fig. 7).

\subsection{Fluvial control on the forme tu nf aeolian features.}

\subsubsection{Riverine parak $\cdot$ lic cunes.}

Riverine parabolic dunes similar : those presented above have been described along the Xiangshui and Laoha rivers in NE Ch na (Wang et al., 2019) (SupFig. 3). The authors proposed a "blowout" type model for the formatic. of the dunes (see Fig. 6 for a simplified wind-pattern model): the airflow is disturbed by the topographic obstacle created by the river valley (Bullard et al., 2000) and accelerates up the downwind bank similar to the airflow accelerating up a ridge (Hunt et al., 1978; Smyth, 2016; Liu et al., 2019). The wind-flow acceleration increases the surface shear stress that reaches a maximum along the crest of the obstacle (in this case the top of the riverbank), inducing erosion and deflation. On crossing the crest, the flow decelerates sharply, decreasing the surface shear stress and forming a wake zone that allows sand deposition and the formation of the riverine parabolic dunes. The largest dunes are formed close to the river and the sand is then re-mobilized by 
the wind along the edges of the dunes, propagating the dune-tip downwind. This model implies that the sand forming the riverine dunes is brought into the system partly by the regional aeolian load but mainly from the river load mobilized by the airflow directly from sand bars in the riverbed or from the banks (Muhs et al., 1996; O’Connor and Thomas, 1999; Bullard et al., 2000; Draut, 2012; Thomas and Bailey, 2017; Sankey et al., 2018; Wang et al., 2019).

This model can be applied to our study area (Fig. 7): the wind blowing from the east interacts with the $\mathrm{N}-\mathrm{S}$ directed incised rivers leading to the formation of extensive riverine dunes on the western side of the valleys (Figs. 2 and 5). West of the Cubango River, rivers flow into the tectonically stable Etosha pan system (Owambo Basin) in Namibia (Fig. 1) (see Niipale and Cuando rivers on

Fig. 2). Although the wind regime and climate remain ident $c_{a} t^{t} \cdot e$ very shallow river valleys in the lowlands do not represent a sufficient topographic $\mathrm{c}^{\mathrm{l}}$ stac'e to the wind flow to develop large riverine dunes. The Angolan rivers carry a lot of fi c $c$ - grained sand eroded from the aeolian-alluvial Kalahari Group series that covers most of the . giı $n$ (Haddon and McCarthy, 2005) (SupFig. 2). As already suggested by Thomas (1988), a non-n`_ligible part of the sand forming the riverine dunes might be of alluvial origin, directly bl $\lrcorner$ - trom the sand bars inside the river and explaining the large volume of those dunes.

\subsubsection{Foredl nes.}

We interpret the river-parall 1 dune cordons as established foredunes, similar to those developing from trapping of aeolian sand by vegetation along beaches (e.g., Short and Hesp, 1982; Bauer and Sherman, 1999; Bauer et al., 2012; García-Romero et al., 2021). Unlike the generally poorly organized incipient foredunes that develop on grassy vegetation, established foredunes are often associated to complex vegetation systems including woody species. In coastal areas, their growth and dynamics depend on several parameters such as the rate of aeolian sand supply and erosion, the amount and type of vegetation cover, or wave-driven erosion and water level fluctuation (e.g., Hesp, 2002). As detailed above, in our study area the aeolian sand is largely sourced from the fine-grained 
material transported by the rivers (supply rate can be considered as nearly constant). This recycling allows for aeolian sand transport even during relatively wet periods usually considered as poorly compatible with dune formation (Thomas et al., 2000, 2003). North of $16^{\circ} \mathrm{S}$, the position of the riverbanks has been largely stable during the time needed for the formation of the dunes, there is no erosion linked to waves, and vegetation has remained dense and woody for at least most of the Quaternary (Malhi et al., 2013). However, alternation of drier periods as indicated, for example, by the chronology of formation of the lunette dunes associated to the Zambian dambos (O'Connor, 1997; Burrough et al., 2015), allowed for periods of increased du.^ activity. A drier climate makes for longer low-flow periods for the fluvial system, exposing the floo lplains to greater deflation and favoring the growth of riverine dunes (Mush and Holliday 1995, Mush et al., 1996; Kocurek and Lancaster, 1999). The continuous deflation of fluvial sa' d, c mbined with the peculiar wind pattern produced by the incised valleys, allowed for the $f_{\Omega 1}$, ation of large foredunes. Through time, the foredunes migrate downwind leaving a "winr.' "arı. 'e" along the riverbank on which a second dune may develop (Figs. 5, 7 and SupFig. 1).

\subsection{Retro-active influence $c_{J}^{\dagger}$ dun progradation on the river network.}

While the occurrence of rivers $L^{\top}$ ds to the formation of the aeolian pattern described above, the dynamics of those dune fic ids, lso controls the drainage pattern by forcing some of the rivers to migrate westward over sever 1 tens of kilometers, explaining their arcuate shape (Fig. 7).

North of $16^{\circ} \mathrm{S}$, the foredunes underlining the western banks of the rivers are largely stabilized by dense vegetation cover, only slowly migrating westward. In contrast, in the driest lowlands south of $16^{\circ} \mathrm{S}$, the sand initially deposited in the parabolic riverine dunes is remobilized and transported farther west by the wind, forming extensive dune fields (Figs. 1 and 2). The migrating dunes finally reach the next river, bringing a considerable volume of aeolian sand on the eastern bank. Dunes invading the river valleys are clearly visible in the Cuafir and Cuatir rivers (SupFig. 2). When the apparent water flux is limited, such as in the Cuafir, Cuatir and Cueio rivers, alluvial transport 
capacities are not sufficient to compensate aeolian deposition (in the absence of available flux measurements, the apparent water flux of the river is estimated relative to the geometry (width, meandering, continuity) of the active river (SupFig. 2). This phenomenon, associated with the preferential aeolian and fluvial erosion of the western bank of the valleys, forces the river to migrate westward, forming the large-scale releasing bends observed in the study area (Figs. 2 and 7). Unlike in the Chinese example where the riverbed is not shifted by the propagation of the dune field (SupFig. 3), in the Angolan example, the migration of the riverbed is facilitated by the weakly consolidated upper Kalahari Fm. deposits forming the substratum. this unconsolidated surface layer facilitates wind abrasion and fluvial incision of the downwind ri erb $\mathrm{nk}$.

When the apparent water flux is large enough, such as it the Lubango or Cuito rivers, alluvial transport capacities compensate (and probably exceed) the aeolian deposition capacities (SupFig. 2). The river course is not diverted and this stabili y allows for the development of an established foredune along the western bank (Fig. 2). To s. sith, the rivers merge, the Cuafir with the Cuatir, the Cueio with the major Cubango, and the L assinga with the Cuito, which stops the westward migration system by increasing the all . v ${ }^{1}$ transport capacities. Finally, the Cueio River illustrates the ultimate step in the aeolian mc.lification of the drainage system: the river migrated westward toward the stable Cubango valle, lie distance between the two rivers decreased and the Cueio finally managed to break th rou $\mathrm{h}$ the parabolic riverine dunes on its western flank abandoning the southern part of its arcuate p leo-valley (Fig. 2).

\section{Conclusions}

The incised drainage system on the southern slopes of the Angolan plateau and in the northern Kalahari generates local perturbations in the near-unidirectional E-W wind system characterizing that region. These perturbations associated to the availability of fine-grained clastic material in the riverbeds triggered the formation of foredunes and riverine parabolic dunes along the west bank of 
the rivers. The preferential development of foredunes over parabolic dunes is linked to a denser and more complex vegetation cover and to the higher transport capacity of the river. The morphology of the drainage system thus drives the formation, characteristics and evolution of dune fields in that region. In parallel, aeolian processes can have a major influence on the shape and dynamics of a drainage system at a regional scale. The alignment of the secondary rivers with the direction of the major dune fields was already largely established. However, the large-scale diversion of the trunk rivers, facilitated by an easily erodible substratum, an existing but limited vegetation cover, a low transport capacity and a near-perpendicular angle between the rind and river direction was not documented. The impact of this mechanism on river-capture prı ces` es in semi-arid regions, on the geometry of clastic deposits in sedimentary basins (hor :s ach mechanism recorded in the sedimentary archives?) or on source-to-sink budgets hov much of the preserved sediment is brought from outside the system by recycling of $w$ ndblown material in rivers?) remains to be explored. Finally, the ongoing aridification $1 .{ }^{1}$ eci to climate change may increase the interactions between rivers and dunes fields: a decrease in vegetation cover should increase aeolian transport, decrease the transport capacity of rivers: cd thus facilitate the formation and migration of riverine parabolic dunes.

\section{Acknowledgements}

This research was supported by a CNRS - INSU International Emerging Action Program and was conducted in the framework of the CNRS GDR-Rift collaboration program (https://rift-cnrs.fr). We thank C. Narteau and L. Barrier for highly constructive discussions during the preparation of the manuscript. Comments by N. Lancaster and D.S.G Thomas on the initial manuscript and corrections and suggestions by the Editor S.A. Lecce were greatly appreciated. 


\section{References}

Abdourhamane Touré, A., Tidjani, A.D., Rajot, J.L., Marticorena, B., Bergametti, G., Bouet, C., Ambouta, K.J.M., Garba, Z., 2019. Dynamics of wind erosion and impact of vegetation cover and land use in the Sahel: A case study on sandy dunes in southeastern Niger. Catena, 177, 272-285.

Albritton C.C., Brooks J.E., Issawi B., Swedan A., 1990. Origin of the Qattara Depression, Egypt. Geological Society of America Bulletin, 102, 952-960.

Bailey, R.M., Thomas, D.S.G., 2014. A quantitative approach to under tanding date dune stratigraphies. Earth Surface Processes and Landform : 0 j14-631.

Bailey, S.D., Bristow, C.S., 2004. Migration of parabolic du te: at Aberffraw, Anglesey, north Wales. Geomorphology, 59 (1-4), 165-174.

Bateman, M.D., Thomas, D.S.G., Singhvi, A.K., 2003. Fxunding the aridity re- cord of the Southwest Kalahari: current problems and $\mathrm{fr} \cdot \mathrm{u}$ e perspec- tives. Quaternary International, 111, 37-49.

Bauer, B.O., Sherman, D.J., 1999. Coastal du. dynamics: problems and prospects. In, Goudie, A.S., Livingstone, I., Stokes, S (E⿺`), Aeolian Environments, Sediments, and Landforms. Wiley, Chichester, 71- 103.

Bauer, B.O., Davidson-Arnott, P G.?., Walker, I.J., Hesp, P.A., Ollerhead, J., 2012. Wind direction and complex sedim -in transport response across a beach-dune system. Earth Surface Processes and Lana. orms, 37, 1661-1677. DOI: 10.1002/esp.3306.

Belnap, J., Reynolds, R.L., Reheis, M.C., Phillips, S.L., Urban, F.E., Goldstein, H.L., 2009. Sediment losses and gains across a gradient of livestock grazing and plant invasion in a cool, semi-arid grassland, Colorado Plateau, USA. Aeolian Research, 1, 27-43.

Bertran, P., Bateman, M.D., Hernandez, M., Mercier, N., Millet, D., Sitzia, L., Tastet, J.P., 2011. Inland aeolian deposits of south-west France: facies, stratigraphy and chronology. Journal of Quaternary Sciences, 26 (4), 374-388.

Boast, R., 1990. Dambos: a review. Progress in Physical Geography, 14, 153-177. 
Bullard, J.E., and Nash, D.J., 2000. Valley-marginal sand dunes in the south-west Kalahari: their nature, classification and possible origins. Journal of Arid Environments, 45, 369-383. https://doi:10.1006/jare.2000.0646

Bullard, J.E., Wiggs, G.F.S., and Nash, D.J., 2000. Experimental study of wind directional variability in the vicinity of a model valley. Geomorphology, 35, 127-143.

Burrough, S.L., Thomas, D.S.G., Bailey, R.M., 2009. Mega-Lake in the Kalahari: A Late Pleistocene record of the Palaeoloake Makgadikgadi system. Quaternary Science Reviews, 28, 1392-1411.

Burrough, S.L., Thomas, D.S.G., Orijemie, E.A., Willis, K.J., $20^{\prime} 5.1$ andscape sensitivity and ecological change in western Zambia: The long-ter $n_{1}$ er , pective from dambo cut-and-fill sediments. Journal of Quaternary Science, 30, 4-5?.

Carvalho, S.C.P., Santos, F.D., and Pulmquério, M. ¿17. Climate change scenarios for Angola: an analysis of precipitation and temper $\cdots$ ' ${ }_{\uparrow}{ }_{\vdash}$ rojections using four RCMs. International Journal of Climatology, 37, 3398-341 ¿ https://doi.org/10.1002/joc.4925.

Carr, A.S., Armitage, S.J., Berrío, J-C., s1 'sao, B.A., Boom, A., 2016. An optical luminescence chronology for late Pleistorene ceolian activity in the Colombian and Venezuelan Llanos. Quaternary Research, 8: 2৬9-312.

Chidumayo, E.N., 2016. Cl 'ssij cation of Forests in Zambia. Ministry of Lands Natural Resources and Environmental 'rotection, Integrated Land Use Assessment Phase II - Technical Paper 1. Food and Agricultural Organization of the United Nations, Ministry of Foreign Affairs Finland. Lusaka, Zambia

Church, M., 1992. Channel morphology and typology. In Calow, P., and Petts, G.E., (eds.), The rivers handbook: hydrological and ecological principles. Malden, Blackwell Scientific Publications, 1, $526 \mathrm{p}$.

Conway, D., van Garderen, E.A., Deryng, D., Dorling, S., Krueger, T., Landman, W., Lankford, B., Lebek, K., Osborn, T., Ringler, C., Thurlow, J., Zhu, T., Dalin, C., 2015. Climate and 
southern Africa's water-energy-food nexus. Nature Climate Change, 5, 837-846, DOI: 10.1038/NCLIMATE2735.

Day, M., Gumbo, D., Moombe, K.B., Wijaya, A., Sunderland, T. ,2014. Zambia country profile: Monitoring, reporting and verification for REDD+. Center for International Forestry Research (CIFOR), Occasional Paper 113. Bogor, Indonesia. ISBN 978-602-1504-42-0.

De Araújo, A.G., Perevalov, O.V., Jukov, R.A., 1988. Carta geológica de Angola, 1:1000 000, Folha 3, Instituto Nacional de Geologia, Ministério da Indústria, República Popular de Angola.

De Carvalho, H., Tassinari, C., Alves, P.H., Guimarães, F., Simões, M.C., 2000. Geochronological review of the Precambrian in western Angola: links witl Brc zil. Journal of African Earth Sciences, 31, 383-402.

Draut, A.E., 2012. Effects or river regulation on aeolian and capes, Colorado River, southwestern USA . Journal of Geophysical Research, 1'-1. F02022. https://doi.org/10.1029/2011JF0023르

García-Romero, L., Hernández-Cordero, A.I., I`sp, P.A., Hernández-Calvento L., Santana del Pino, A., 2021. Decadal monit, $\mathrm{rl}$. of Traganum moquinii's role on foredune morphology of an human impacted arid lunt:ield. Science of the Total Environment, 758, 143802, https://doi.org/10.1016/].. ilutenv.2020.143802.

Goudie A.S., 1991. Pans. P. ogre ss in Physical Geography, 15.3, 221-237.

Goyder, D.J., Barker, N., Be. ter, S.P., Frisby, A., Janks, M., Gonçalves, F.M.P., 2018. The Cuito catchment of the Okavango system: a vascular plant checklist for the Angolan headwaters. PhytoKeys, 113, 1-31. https://doi.org/10.3897/phytokeys.113.30439.

Haddon, I.G., and McCarthy, T.S., 2005. The Mesozoic-Cenozoic interior sag basins of Central Africa : The Late-Cretaceous-Cenozoic Kalahari and Okavango basins . Journal of African Earth Sciences, 43, 316-333. https://doi.org/10.1016/j.jafrearsci.2005.07.008.

Hanson, R.E., 2003. Proterozoic geochronology and tectonic evolution of Southern Africa. In: Yoshida, M., Windley, B.F. \& Dasgupta, S. (eds) Proterozoic East Gondwana: 
Supercontinent Assembly and Breakup. Geological Society, London, Special Publications,

206, 427-463.

Hesp, P., 2002. Foredunes and blowouts: initiation, geomorphology and dynamics. Geomorphology,

48, 245-268.

Hesse, P.P., and Simpson, R.L., 2006. Variable vegetation cover and episodic sand movement on longitudinal desert sand dunes. Geomorphology, 81, 276-291.

Holmes, P.J., Thomas, D.S.G., Bateman, M.D., Wiggs, G.F.S., Rabumbulu, M., Evidence for land degradation from aeolian sediment in the west-central Frc $\sim$ State Province, South Africa. Land Degradation \& Development, 23, 601-610.

Hunt, J.C.R, Abell, C.J., Peterka, J.A., and Woo, H., 1978. Y.iı॰m ^tical studies of the flows around free or surface-mounted obstacles ; applying tc: olo; y to flow visualization. Journal of Fluid Mechanics, 86(1), 179-200.

Huntley, B.J., 2019. Angola in outline: Physir o ap. clie, climate and patterns of biodiversity: in Huntley, B.J., Russo, V., Lages, F., Feı. ^nd, N. (eds), Biodiversity of Angola, Science \& Conservation: A Modern Syntl es i Jpringer Open, https://doi.org/10.1007/978-3-03003083-4.

Kocurek, G., Lancaster, N., 1999. Aevlian system sediment state: theory and Mojave Desert Kelso dunefield example Secimentology, 46, 505-515.

Kottek, M., Grieser, J., Berk C., Rudolf, B., Rubel, F., 2006. World map of the Köppen-Geiger climate classification updated. Meteorologische Zeitschrift, 15, 259-263.

Krapf, C.B.E., Stollhofen, H., and Stanistreet, I.G., 2003. Contrasting styles of ephemeral river systems and their interaction with dunes of the Skeleton Coast erg (Namibia). Quaternary International, 104, 41-52.

Lancaster, N., 2009. Dune morphology and dynamics. In Parsons, A.J., and Abrahams, A.D. (Eds.), Geomorphology of desert environments, $2^{\text {nd }}$ Edition, Springer Science+Business Media, doi:10.1007/978-1-4020-5719-9 
Li, X., Yan, P., Liu, B., 2020. Geomorphological classification of aeolian-fluvial interactions in the desert region of north China. Journal of Arid Environments, 172, 104021, https://doi.org/10.1016/j.jaridenv.2019.104021

Li, X., Yan, P., Cao, L., Liu, B., 2021. Distinct aeolian-fluvial interbedded landscapes in three watersheds of the northern China. Chinese Geographical Science, https://doi.org/10.1007/s11769-021-1211-y

Liu, B., and Coulthard, T.J., 2017. Modelling the interaction of aeolian and fluvial processes with a combined cellular model of sand dunes and river system: Computers \& Geosciences, 106, 1-9. http://dx.doi.org/10.1016/j.cageo.2017.05.003

Liu, Zh., Diao, Zh., and Ishihara, T., 2019. Study of the f'o " f'elds over simplified topographies with different roughness conditions using larg e eda / simulations. Renewable Energy, 136, 968-992. https://doi.org/10.1016/j.renene.2 2 - 2 2 01.032.

Malhi, Y., Adu-Bredu, S., Asare, R.A., Lev i. S. I., Mayaux, P., 2013. African rainforests: past, present and future. Philosophical Tru.'sactions of the Royal Society, B, 368, 20120312. http://dx.doi.org/10.1098/rstb. $\underline{\text { u }}$ ? 2 (1312.

Maroulis J.C., Nanson G.C., Price F M., Pietsch T., 2007. Aeolian-fluvial interaction and climate change: source-bordering dune development over the past 100 ka on Cooper Creek, central Australia. (uat rnary Science Reviews, 26, 386-404.

McFarlane, M.J., Eckardt, F. )., Ringrose, S., Coetzee, S.H., Kuhn, J.R., 2005. Degradation of linear dunes in northwest Ngamiland, Botswana and the implications for luminescence dating of periods of aridity. Quaternary International, 135, 83-90.

Moore, A.E., Cotterill, F.P.D., and Eckardt, F.D., 2012. The evolution and ages of Makgadikgadi palaeo-lakes: consilient evidence from Kalahari drainage evolution south-central Africa. South African Journal of Geology, 115(3), 385-413. https://doi.org/10.2113/gssajg.115.3.385 
Muhs, D.R., Holliday, V.T., 1995. Evidence of active dune sand on the Great Plains in the $19^{\text {th }}$ Century from accounts of early explorers. Quaternary Research, 43, 198-208.

Muhs, D.R., Stafford, Th.W., Cowherd, S.D., Mahan, Sh.A., Kihl, R., Maat, P.B., Bush, Ch.A., and Nehring, J., 1996. Origin of the late Quaternary dune fields of northeastern Colorado. Geomorphology, 17, 129-149.

Munyikwa, K., Van den Haute, P., Vandenberghe, D., De Corte, F., 2000. The age and palaeoenvironmental significance of the Kalahari Sands in western Zimbabwe: a thermoluminescence reconnaissance study. Journal of Afi : ran Earth Sciences, 30, 941956.

Muñoz-Sabater, J., 2019. ERA5-Land monthly averaged da a a "or 1981 to present. Copernicus Climate Change Service (C3S) Climate Data S+ re ( CDS). (12-2020), $10.24381 /$ cds. $68 \mathrm{~d} 2 \mathrm{bb} 30$

O’Connor, P.W., 1997. Aeolian activity and e`...ro.'mental change in the Central Mega Kalahari: Implications for the timing, nature anu auses of the Late Quaternary aridity. PhD Thesis. Department of Geography, Un vt, rity of Sheffield.

O’Connor, P.W., and Thomas, D.S.C , 1399. The timing and environmental significance of Late Quaternary linear dune aiveiopment in Western Zambia. Quaternary Research, 52, 44-55. Riedel, F., Henderson, A.C. J., I’eußner, K-U., Kaufmann, G., Kossler, A., Leipe, Ch., Shemang, E., Taft, L., 2014. Dyna nics of a Kalahari long-lived mega-lake system: hydromorphological and limnological changes in the Makgadikgadi Basin (Botswana) during the terminal 50 ka. Hydrobiologia, 739, 25-53.

Ringrose, S., Huntsman-Mapila, Ph., Kampunzu, A.B., Downey, W., Coetzee, S., Vink, B., Matheson, W., Vanderpost, C., 2005. Sedimentological and geochemical evidence for palaeo-environmental change in the Makgadikgadi subbasin, in relation to the MOZ rift depression, Botswana. Palaeogeography, Palaeoclimatology, Palaeoecology, 217, 265287. 
Rosgen, D.L., 1994. A classification of natural rivers. Catena, 22, 169-199.

Sankey, J.B., Kasprak, A., Caster, J., East, A.E., and Fairley, H.C., 2018. The response of sourcebordering aeolian dunefields to sediment-supply changes 1: Effects of wind variability and river-valley morphodynamics. Aeolian Research, 32, 228-245.

https://doi.org/10.1016/j.aeolia.2018.02.005.

Short, A.D., Hesp, P.A., 1982. Wave, beach and dune interactions in South Eastern Australia. Marine Geology, 48, 259-284. DOI: 10.1016/0025- 3227(82)90100- 1.

Smyth, Th.A.G., 2016. A review of Computational Fluid Dynamic: (CFD) airflow modelling over aeolian landforms. Aeolian Research, 22, 153-164. http://dx.doi.org/10.1016/j.aeolia.2016.07.003

Stokes, S., Thomas, D.S.G., and Washington, R., 1997. ^ Yult ple episodes of aridity in southern Africa since the last interglacial period. Nc u, 2 388, 154-158.

Stokes, S., Haynes, G., Thomas, D.S.G., Hor u ks, '.L., Higginson, M., Malifa, M., 1998. Punctuated aridity in southern Africa u. ring the last glacial cycle: the chronology of linear dune construction in the north as s $r n$ Kalahari. Palaeogeography, Palaeoclimatology, Palaeoecology, 137, 305-3'?2.


Kalahari, Namibia. cha lenges of reconstructing late Quaternary palaeoenvironments from aeolian landforms (_uaternary Science Reviews, 27, 1667-1681.

Swezey, C.S., Fitzwater, B.A., Whittecar, G.R., Mahan, S.A., Garrity, C.P., Alemán Gonzáles, W.B., Dobbs, K.M., 2016. The Carolina Sandhills: Quaternary eolian sand sheets and dunes along the updip margin of the Atlantic Coastal Plain province, southeastern United States. Quaternary Research, 86, 271-286.

Telfer, M.W., 2011. Growth by extension, and reworking, of a south-western Kalahari linear dune. Earth Surface Processes and Landforms, 36, 1125-1135. https://doi.org/10.1002/esp.2140 
Telfer, M.W., and Thomas, D.S.G., 2007. Late Quaternary linear dune accumulation and chronostratigraphy of the southwestern Kalahari: implications for aeolian palaeoclimatic reconstructions and predictions of future dynamics. Quaternary Science Reviews, 26, 2617-2630. https://doi.org/10.1016/j.quascirev.2007.07.006

Thomas, D.S.G., 1984, Ancient ergs of the former arid zones of Zimbabwe, Zambia and Angola: Transactions of the Institute of British Geographers, v. 9, p. 75-88.

Thomas, D.S.G., 1988. The geomorphological role of vegetation in the dune systems of the Kalahari: In "Geomorphological Studies in Southern Afri »", Dardis, G.F., and Moon, B.P. (Eds.), p. 145-158. Balkema, Rotterdam.

Thomas, D.S.G., and Shaw, P.A., 1991. The Kalahari Envirr n. eer : Cambridge University Press, Cambridge. ISBN 0-521-37080-9

Thomas, D.S.G., Stokes, S., Shaw, P.A., 1997. Holr « ie aeolian activity in the southwestern Kalahari Desert, southern Africa: $\operatorname{sic}_{\text {.A. }}{ }^{\circ}$ icance and relationships to late- Pleistocene dune- building events. The Holocene, i, 273-281.

Thomas, D.S.G., O’Connor, P.W., Bate nə « M.D., Shaw, P.A., Stokes, S., and Nash, D.J., 2000. Dune activity as a record oi late Quaternary aridity in the Northern Kalahari: new evidence from northern Namibia il ‘ arpreted in the context of regional arid and humid chronologies. Palaeogeography, Dala ?oclimatology, Palaeoecology, 156, 243-259.

Thomas, D.S.G., Brook, G 'shaw, P., Bateman, M., Haberyan, K., Appleton, Ch., Nash, D., McLaren, S., and Davies, F., 2003. late Pleistocene wetting and drying in the NW Kalahari: an integrated study from the Tsodili Hills, Botswana. Quaternary International, 104, 5367.

Thomas, D.S.G., Leason, H.C., 2005. Dunefield activity response to climate variability in the southwest Kalahari. Geomorphology, 64, 117-132. 
Thomas, D.S.G., Burrough, S.L., 2012. Interpreting geoproxies of late Quaternary climate change in African drylands: Implications for understanding environmental change and early human behaviour. Quaternary International, 253, 5-17.

Thomas, D.S.G., Bailey, R.M., 2017. Is there evidence for global-scale forcing of Southern Hemisphere Quaternary desert dune accumulation? A quantitative method for testing hypothesis of dune system development. Earth Surface Processes and Landforms, $\mathbf{4 2 ,}$ 2280-2294.

Wang, Y., Yan, P., Han, G., Wu, W., and Zhang, R., 2019. Sand sol ree and formation mechanism of riverine sand dunes: a case study in Xiangshui River, Cl ina. Journal of Arid Land, 11(4), 525-536. https://doi.org/10.1007/s40333-019-0102 x.

Wasson, R.J., Nanninga, P.M., 1986. Estimating wind tr` nspı rt of sand on vegetated surfaces. Earth Surface Processes and Landforms, 11, 505 j: 4.

Wessel, P., Smith, W.H.F., 1991. Free softwar_ '- $\mathrm{e}_{\mathbf{r}} `$ map and display data. EOS Trans. Am. Geophys. Union, 72 (441), 445-446.

Wiggs, G.F.S., Thomas, D.S.G., Bullarr, ‘. . 1995. Dune mobility and vegetation cover in the southwest Kalahari desert. artı Surface Processes and Landforms, 20, 515-529.

Williams M., 2015. Interactions 'hetween fluvial and aeolian geomorphic systems and processes: Examples from the Sahi ra and Australia. Catena, 134, 4-13.

Wormald R.J., Eckardt F.D.. Vearncombe J. and S., 2003. Spatial Distribution Analysis of Pans in Botswana: The Importance of Structural Control. South African Journal of Geology, 106, 287-290.

Yizhaq, H., Ashkenazy, Y., Tsoar, H., 2007. Why do active and stabilized dunes coexist under the same climatic conditions? Physical Review Letters, 98, 188001, DOI: 10.1103/PhysRevLett.98.188001 


\section{FIGURE CAPTIONS}

Figure 1. General map of southern Africa showing the main rivers, dune fields and tectonic or topographic features discussed in the text.

Figure 2. Climate and topography of the southern Angolan plateau - northern Kalahari basin. A Annual total precipitation in southern Africa (modified from Conway et al., 2015). Rectangles labelled B and C correspond to the area represented in Figs. 2B and 2C. B - Simplified KöppenGeiger climate map highlighting the transition between equai oria to warm temperate and arid around $16^{\circ} \mathrm{S}$ in Angola. Climate labels correspond to th ₹ $\mathrm{Y}_{\mathrm{o}}$, pen-Geiger (map modified from Kotteck et al., 2006). C - Topographic map obtained fre n Sı 'TM-1 data of the study area extending between the Cubango and Cuito rivers. The rose $\ldots$ il gram represents the wind direction obtained over the whole region from the Copernicur $5 \mathbf{F}^{\wedge} 5$-Land monthly average model for the period January 2017 to December 2019 ( $\mathrm{N}$ is the nu. ber of observations). The white-shaded rectangles show the location of the stack topogra $n$ : nrofiles reported in Figs. 4B and 4D. The dotted white line corresponds to the limit betwec $\urcorner$ the warm temperate (Cwa) and arid (BSh) climate zones. D Geological map of the study area :ased on De Araújo et al. (1988). In the Kalahari Group, the "Grés polimorphos" Formation c rre pond to the basal alluvial conglomerates unit (Eocene to early Miocene); the Undifferentiat dd Eocene - Pliocene unit corresponds to calcareous clay deposits; the "Areias ocres" Formation corresponds to the poorly indurated fluvial sandstones unit (Miocene Pliocene); the Undifferenciated Quaternary, Holocene alluvium and Aelian deposits units correspond to the youngest, unconsolidated series (see text for a description of the units). The brown dotted lines indicate the estimated thickness of the Kalahari Group sediments (labels in meters) (see also Haddon and McCarthy, 2005). 
Figure 3: Satellite images of various types of dunes forming the northern Kalahari dune field (images are taken from Google Earth. A- Landsat/Copernicus image of the extensive linear dunes extending in SE Angola, NE Namibia and north Botswana. The white arrow underlines the long axis of the dunes. B- Maxar Technologies image of vegetated, stabilized parabolic dunes in SE Angola. The dotted lines underline the front of the dunes. C- Maxar Technologies image of a large lunette dune associated to a blowout structure in south Angola. The dotted line approximatively underlines the front of the dune.

Figure 4: A- River longitudinal profiles of the trunk rivers in t. 'e sı ddy area. Profiles begin to the north at the latitude of $15.5^{\circ} \mathrm{S}$ and end to the south either at th $\checkmark \mathrm{c}$,nfluence with another major river or at a latitude of $16.75^{\circ} \mathrm{S}$. The high-frequency noise $\mathrm{i}^{\text {* }}$ the data correspond to uncertainties in the SRTM-1 data. B - Topographic stack profile in the 11 rthern part of the study area (see location on Fig. 2). Profiles were acquired with a $1 \mathrm{~km}{ }_{\sim}$ 'acing from SRTM-1 data; altitude data along each individual profile were sampled every $20 \mathrm{~m} . \mathrm{T}_{\mathbf{L}} \cdot$ colored line corresponds to the mean elevation and the grey envelope represent the elevatir $n$, ariability between profiles. The beige area represents the assumed position of the consolide ed Kalahari Group sediments forming the basement of the uppermost, poorly consolidatea Cenozoic deposits (see Haddon and McCarthy (2005) for a description of the thicknes: ot the Kalahari Group). C- Detailed stack profiles across the Cuito River north of $16^{\circ} \mathrm{S}$ (see loc ttion on Fig. 5A). Profiles were acquired with a $250 \mathrm{~m}$ spacing with altitudes sampled every $20 \mathrm{~m}$. Caption is the same as for Fig. 4B. D- Topographic stack profile in the axial zone of the rivers restraining bends (see location on Fig. 2). Caption and data acquisition is the same as for Fig. 4B.

Figure 5. Topography (A, C) and geomorphological interpretation (B) of a section of the Cuito River showing the large cordon dunes (foredunes) and the terraces along the western bank. West of the foredunes, parabolic dunes are developing, fed by aeolian sand sourced from the foredunes. 
Note that parabolic dunes are also occurring east of the river, belonging to a vast dune field extending between the Cuito River and the Zambezi River system to the east.

Figure 6. Dune pattern across the Lwandilu River, a N-S flowing tributary river in the upper Zambezi drainage system, western Zambia. The formation of elongated, kilometer-scale parabolic dunes on the western flank (downwind flank) of the river is characteristic of the interaction between aeolian and alluvial systems in the entire northern Kalahari. A- Satellite image (Landsat image from Google Earth) showing the parabolic dunes extending on the Liu va Plains wetlands. On the small inset map of Africa, A is Angola, Z is Zambia and the red re tan te indicates the map area. BMorphological map interpreted from image in Fig. 6A. C- Cle ser view of one of the large parabolic dunes shown on Fig. 6A (Maxar Technologies 2021 ima zुe from Google Earth). The dune is strongly vegetated with some densely forested area. 1 - Close view of a transverse dune field in the Liuwa Plains showing the scarce vegetation $\ldots$ ve $e_{1}$ composed of small trees and shrubs. The brown areas correspond to a grassy floodplain (Maxa. Technologies 2021 image from Google Earth). EPoorly vegetated transverse dunes de es_ning immediately downwind of a parabolic dune. The white areas underlining the upwind ide of the dunes corresponds to the non-vegetated active part of the dunes (Maxar Technologies ' $20 ? 1$ image from Google Earth).

Figure 7. Model of large-sc le interaction between aeolian and alluvial processes in the northern Kalahari. A- Schematic 3D representation of the organization of dune fields and topography of the riverbeds. The vegetation cover corresponds to the present-day environment. During the Pleistocene main phase of dune formation, vegetation was probably more restricted. Red arrows indicate the wind direction and relative speed. Numbers 0 to 2 on the section indicate the westward propagation of the riverbed marked by intercalated fluvial and aeolian deposits. B- Corresponding conceptual 2D model: the wind accelerating upslope at the riverbank deflates sand from the riverbed and erodes the bank. The low shear stress wake zone behind the top of the bank allows sand deposition 
and the formation of established foredunes in the most vegetated areas to the north or along the largest and most stable rivers (Cubango and Cuito). When vegetation and river transport capacity decrease (making for a less stable riverbed) because of changes in climate conditions and topographic slopes, parabolic dunes are formed instead of established foredunes. Aeolian material is then transported by wind farther to the next river. When the river transport capacity is low, this excess sediment load forces the river to divert westward (riverbed stages 0,1 and 2). 


\section{Declaration of interests}

$X$ The authors declare that they have no known competing financial interests or personal relationships that could have appeared to influence the work reported in this paper.

$\square$ The authors declare the following financial interests/personal relationships which may be considered as potential competing interests: 


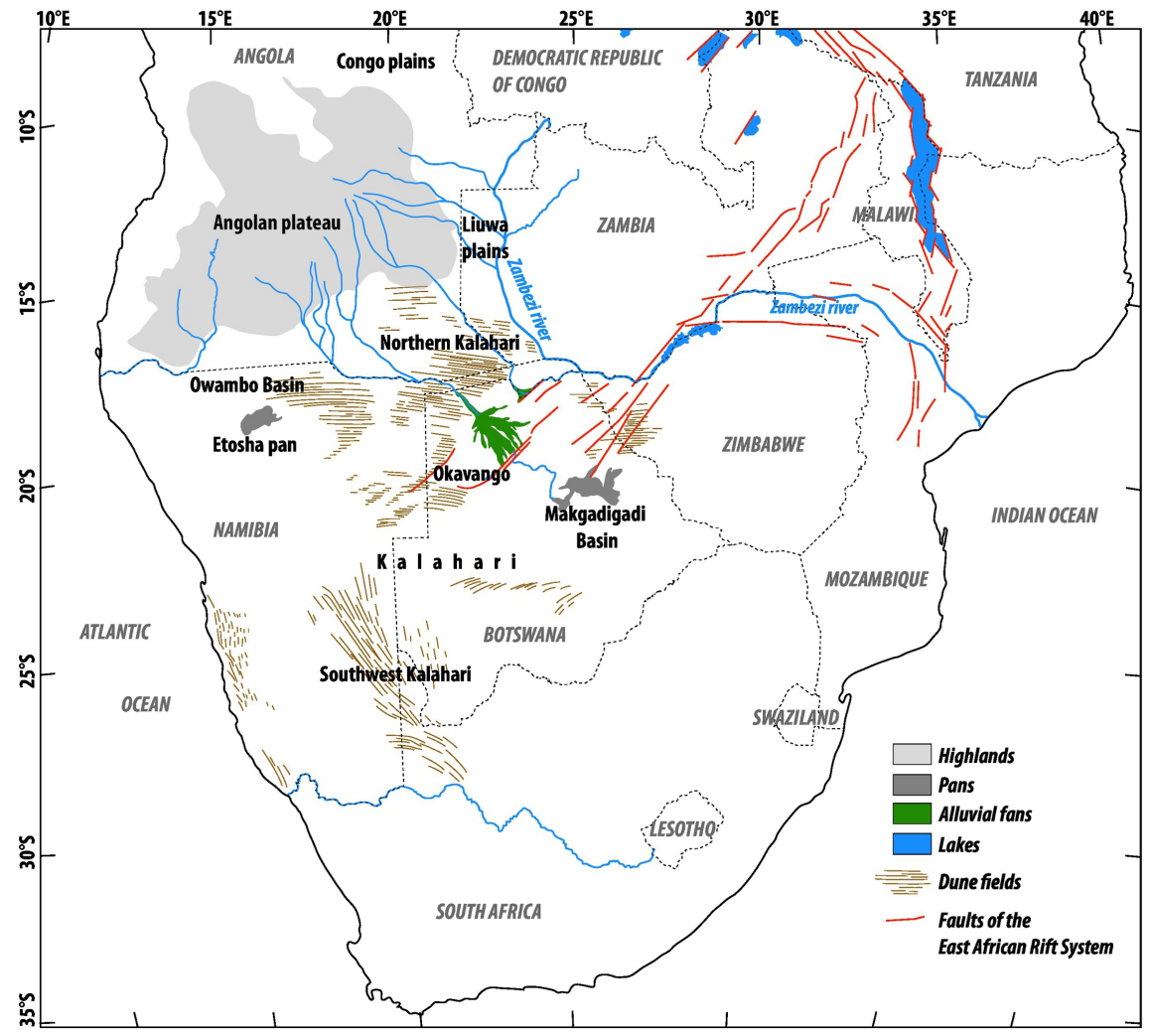

Figure 1 

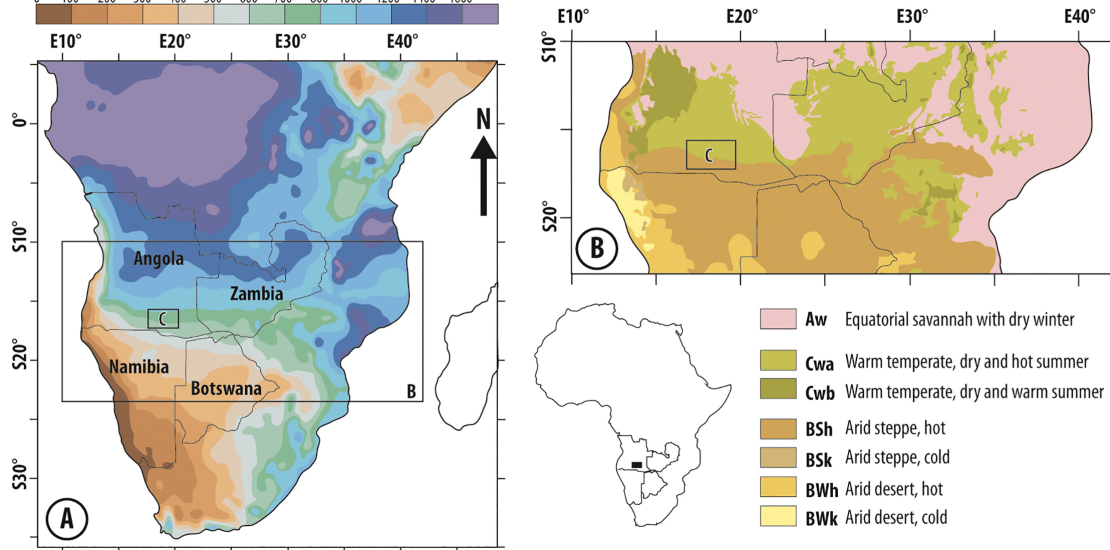

Aw Equatorial savannah with dry winter

Cwa Warm temperate, dry and hot summer

Cwb Warm temperate, dry and warm summer

BSh Arid steppe, hot

BSk Arid steppe, cold

BWh Arid desert, hot

BWk Arid desert, cold
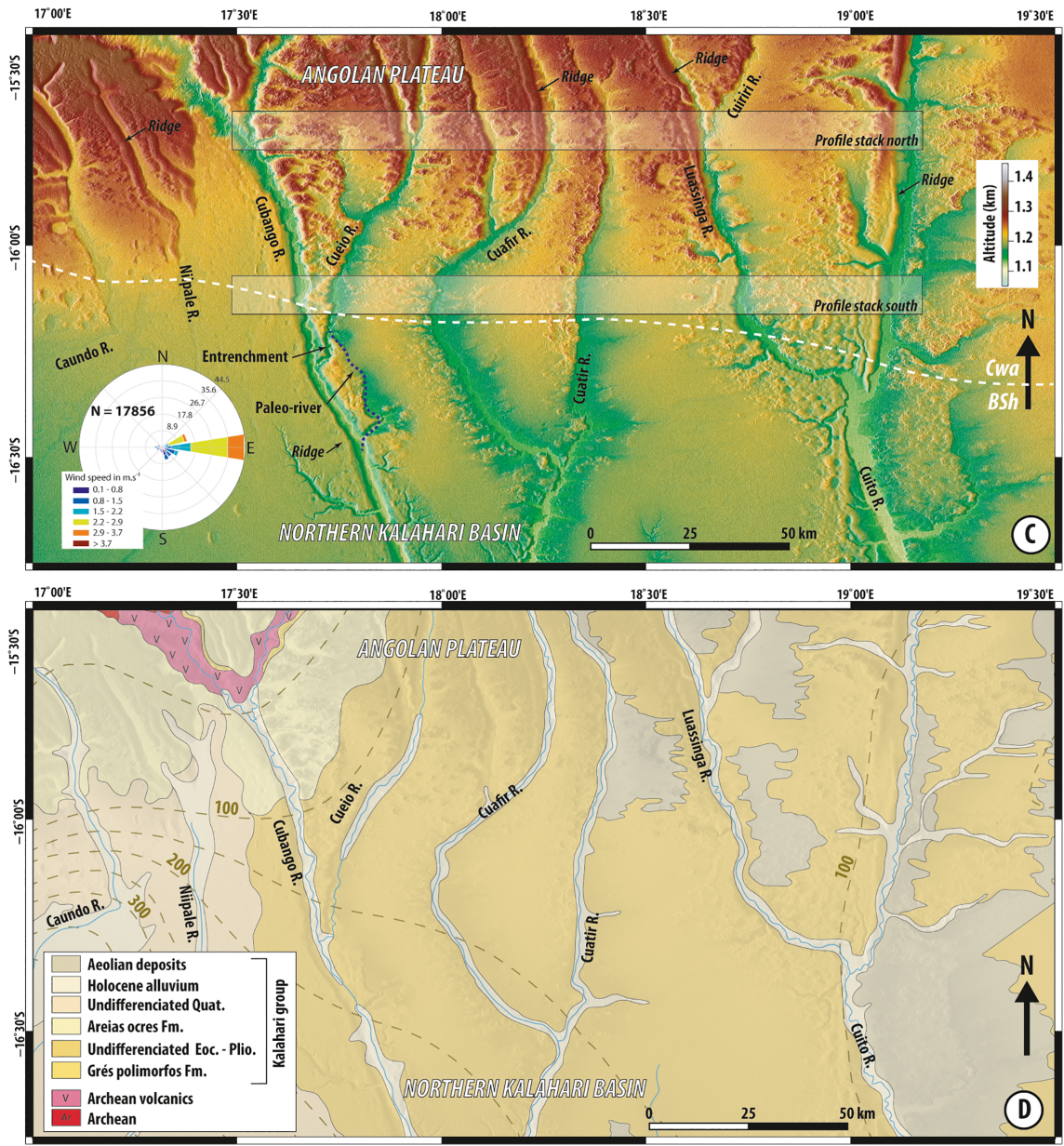

Figure 2 



Figure 3 


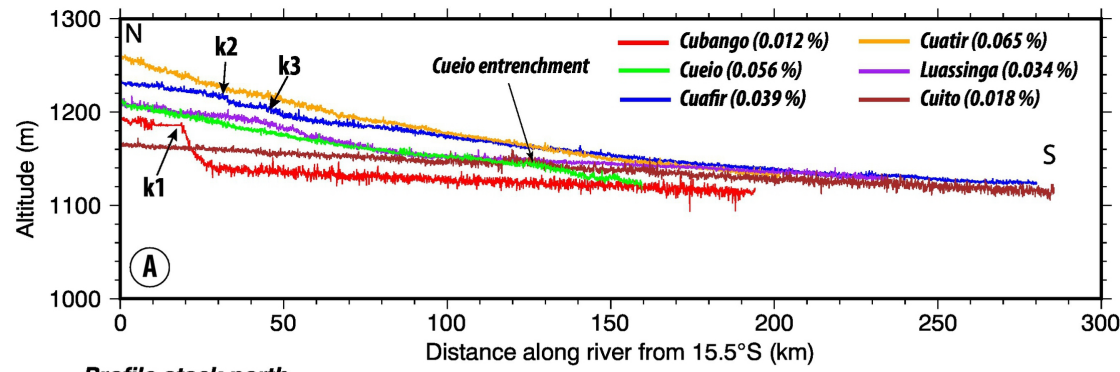

Profile stack north
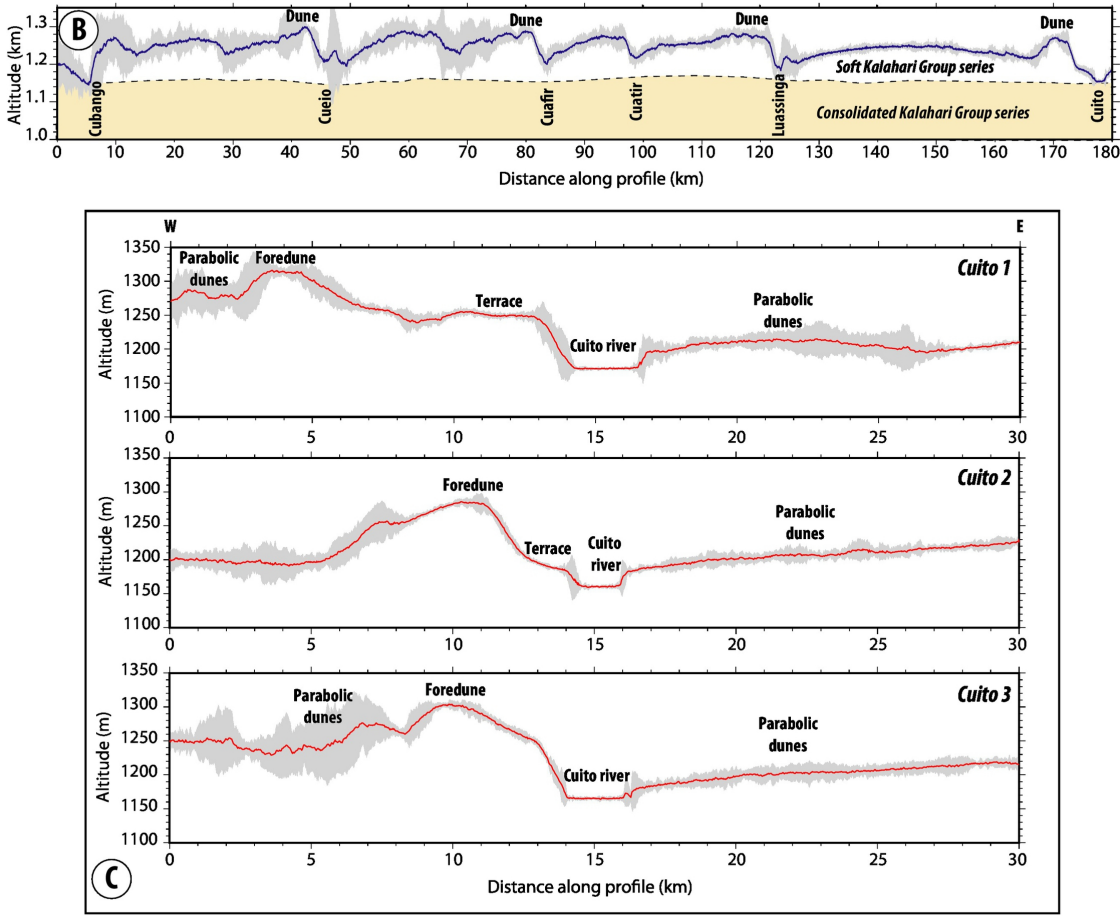

Profile stack south

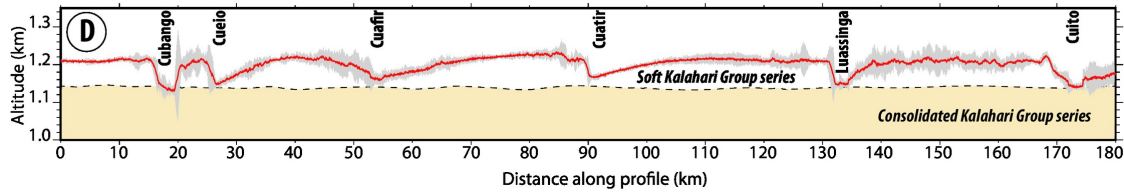



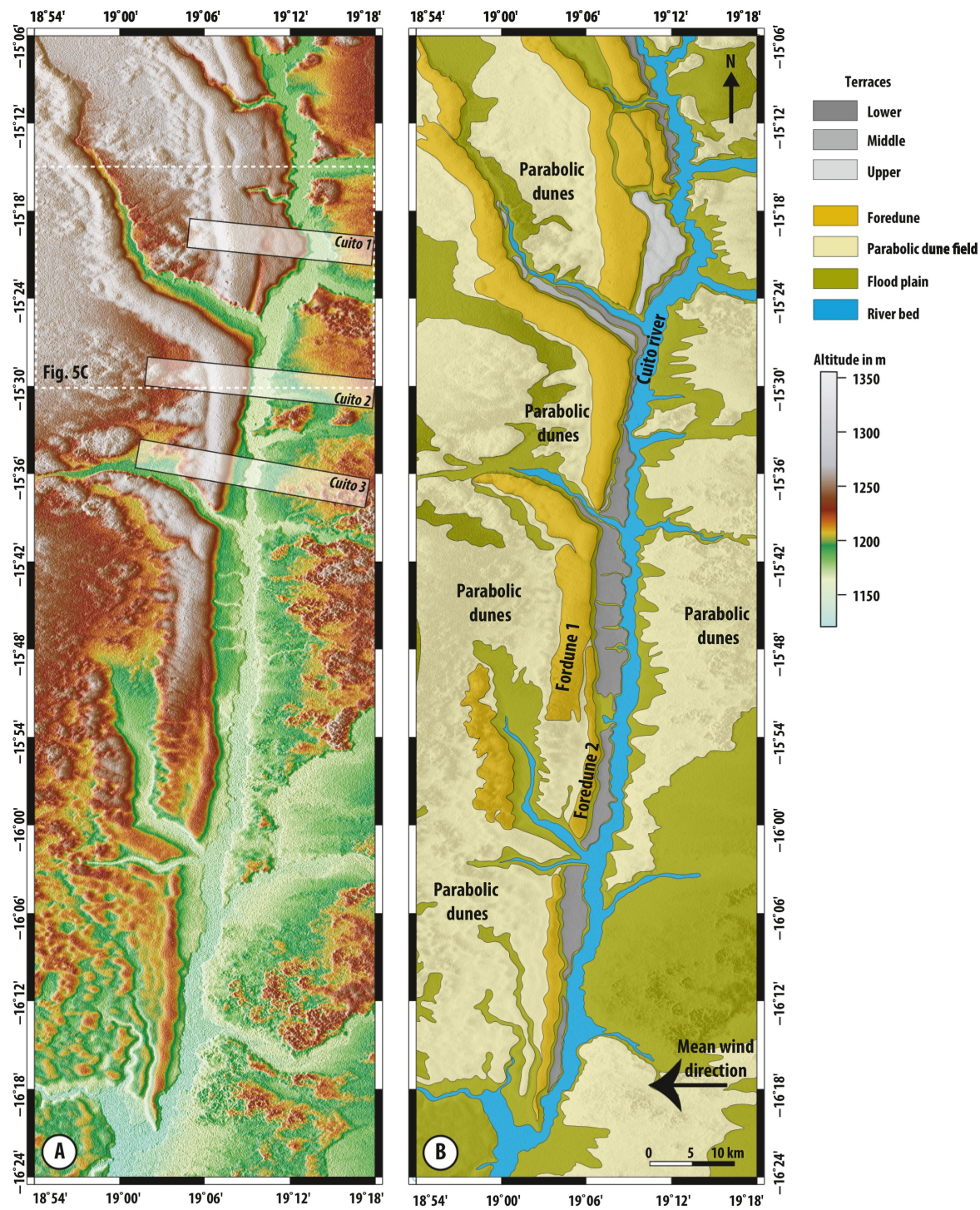

\section{Altitude in $\mathbf{m}$}
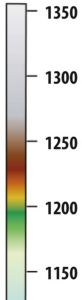

1

$\frac{1}{3}$

is

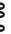

1300

250

1200

1150

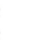

政 

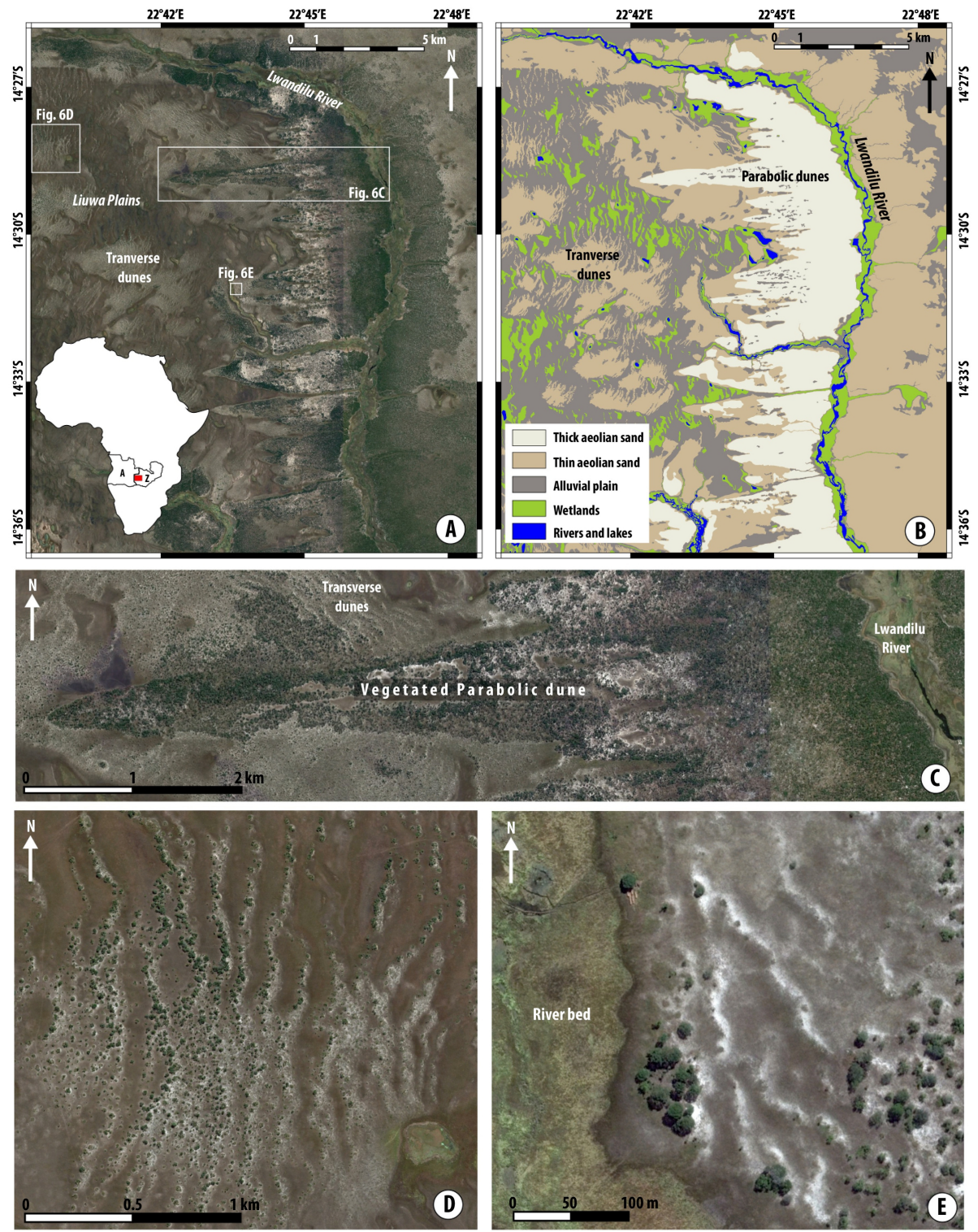

Figure 6 


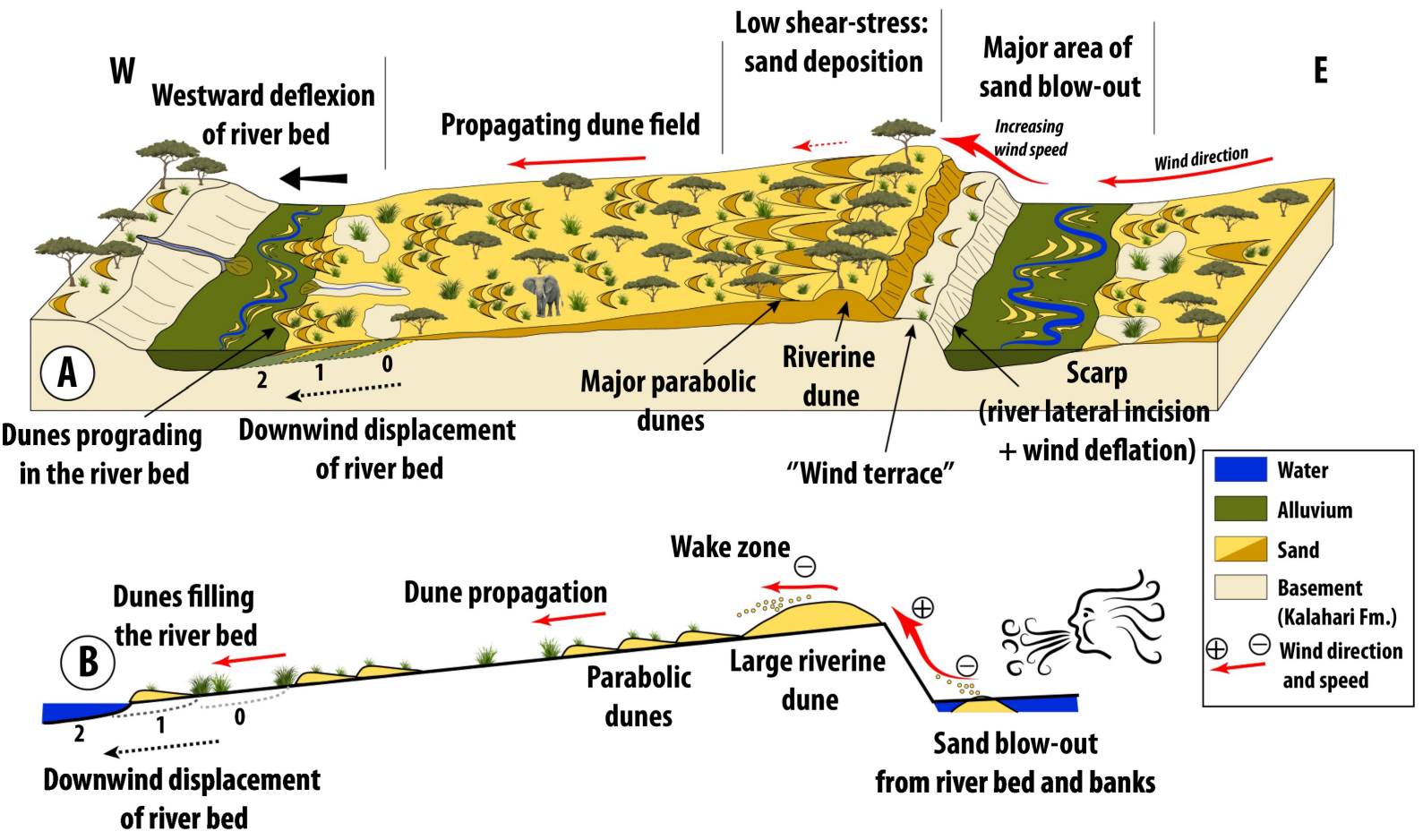

